\title{
Selected Reference Books of 1961-1962
}

\author{
By CONSTANCE M. WINCHELL
}

\section{INTRODUCTION}

T IKE THE preceding articles in this semi$\perp$ annual series, ${ }^{1}$ this survey is based on notes written by members of the staff of the Columbia University libraries. Notes written by assistants are signed with initials, ${ }^{2}$ and for this issue were edited by Eugene Sheehy.

As the purpose of the list is to present a selection of recent scholarly and foreign works of interest to reference workers in university libraries, it does not pretend to be either well-balanced or comprehensive. Code numbers (such as All, 1A26, 2S22) have been used to refer to titles in the Guide $e^{3}$ and its supplements.

\section{BIBLIOGRAPHY}

Berroa, Josefina. Mexico bibliografico, 19571960. Catálogo general de libros impresos en Mexico. Mexico, D.F., the author, 1961. 189p. (Distribution in U.S.A. by R. R. Bowker Co., New York. \$12.)

With the appearance of Fichero bibliografico .... (see below) and the work noted here, librarians and booksellers may indeed be encouraged to expect increasingly better access to current Mexican bibliography. Miss Berroa's list includes more than four thousand titles published in Mexico during the four-year period. Coverage is primarily of trade items, although there are some titles from other sources. Official government publications and new periodicals are apparently excluded. The list is in two parts, the first arranged alphabetically by main entry, with standard bibliographic data and price for each item. In the second half the titles are

${ }^{1} C R L$, January and July issues starting January, 1952.

2 Reference: Eleanor Buist. Rita Keckeissen, Evelyn Lauer, Elizabeth J. Rumics, Eugene Sheehy, John Neal Waddell.

${ }^{3}$ Constance M. Winchell, Guide to Reference Books (7th ed.; Chicago: ALA, 1951); Supplement (Chicago: ALA, 1954); Second Supplement (Chicago: ALA, 1956); Third Supplement (Chicago: ALA, 1960).
Miss Winchell is Reference Librarian, Columbia University Library.

listed under some thirteen hundred subject headings alphabetically arranged. Here bibliographic information is abbreviated. An extensive list of publishers is included. Format and paper are very good.-J.N.W.

Fichero bibliografico hispanoamericano: catalogo trimestral de toda clase de libros publicados en las Americas en español. New York, Bowker, 1961- . v. 1- . Quarterly. $\$ 5$ in Latin America; $\$ 7$ elsewhere.

This new comprehensive bibliography aims to list all new books published in the Americas in the Spanish language in all subjects and by all publishers. Arrangement is by Dewey decimal classification with an index by authors and titles, followed by a list of publishers and a table of conversion for the moneys of the various countries.

Volume 1 , no. 0 , a preliminary issue listing all 1961 books received before October, has been renumbered as vol. 1 , no. 1 .

\section{MicrofiLms}

Philadelphia Bibliographical Center and Union Library Catalogue. Committee on Microphotography. Union List of Microfilms. Cumulation 1949-1959. Ann Arbor, Mich., J. W. Edwards, 1961. 2v. (xviii p., 2800 cols.) $\$ 35$.

As stated in the Introduction, this "is the final publication of the Union List of Microfilms by the Philadelphia Bibliographical Center and Union Library Catalogue" and some new technological solution is needed for effective bibliographic control of microforms in the future.

This final cumulation serves as a companion to the 1951 edition (Supplement 1A17) and includes materials (excepting American dissertations) from the 1949-52 and 
1952-55 supplements, plus listings received through July 1959. Additional locations of positive films of previously reported titles have been added only for the more important manuscripts and early imprints. $\mathbf{L i}$ brarians will want to familiarize themselves with the section of the introduction relating to types of materials omitted.-E.S.

\section{DIRECTORY}

Informator nauki polskiej. 1961. [Warszawa], Panstwowe Wydawnictwo Naukowe, [1961]. 451 p. 40 Zlotys.

For first edition see Supplement 3C5. This is a revised and expanded third edition, greatly improved in format and general reference utility. Information as of July 1, 1960, incorporates changes in organization made in the first half of 1960. There is an index of names of institutions, in addition to the extensive name and address list of Polish scientists. The Table of Contents is translated into English and Russian.-E.B.

\section{ENCYCLOPEDIA}

Aschehougs konversasjons leksikon. 4. utg. Redaksjon: Arthur Holmesland, Alf Sommerfelt $[\mathrm{og}\rceil$ Leif St $\phi$ rmer. Redaksjonssekretar: John Dahl. Oslo, H. Aschehoug, 19541961. 18v. NKr. 67,00 per vol.

An expansion and revision of the third edition (15v. plus supplement, 1939-52; see Supplement 1D9) of a standard Norwegian encyclopedia. The over-all impression is of clear, concise work. Articles vary from one or two lines to many pages; all over six lines are initialed. Bibliographical references are scanty; many small pictures, maps, diagrams, portraits, some in color, are included. Information and statistics are generally not later than 1950-1955, but some 1960 information is included in the later volumes. A supplement is planned for 1962.-E.J.R.

\section{Periodicals and Newspapers}

Arndt, Karl J. R. and Olson, May E. German-American Newspapers and Periodicals, 1732-1955; History and Bibliography. Heidelberg, Quelle \& Meyer, 1961. 794p. \$25. (Deutsche Presseforschung. 3) Distribution in U.S.A. by Clark University Press, Worcester, Mass.
Obviously this volume will prove invaluable to librarians, scholars, researchers, and students in manifold areas, being a great compilation of information and also suggesting many departures for further research. The authors spent over twenty years compiling the list of some five thousand GermanAmerican serials; for each title they give various useful facts including "wherever possible ... exact dates of changes of titles and names of editors and publishers, followed by a list of all holdings located." (Introd.) Arrangement is alphabetical by state and city, with Washington, D. C., first. For each state there is a brief descriptive headnote sketching in broad outline German influence in that state and suggesting sources for further details. Locations are given to files in over three hundred United States libraries and historical societies and fifty European libraries. There are twelve closely-printed pages of select bibliography, works consulted and used, and an index of titles. Title page, introduction and index headnote are bilingual.-E.J.R.

Canadian Index to Periodicals and Documentary Films; an Author and Subject Index, 1948-59. Ottawa, Canadian Library Association, 1962. 1180p. \$120.?

Both the Canadian Library Association and the editors of the volume are to be commended for this time- and space-saving twelve-year cumulation. An author and subject index (see Guide E83 for annual volumes and their predecessors) with many crossreferences in French, the work includes 101 periodical titles for the period, and the documentary output of 29 film producers.-E.S.

Indice general de publicaciones periodicas latinoamericanas. Humanidades y ciencias sociales. Index to Latin American Periodicals. Humanities and Social Sciences. v. 1, no. 1- . lst quarter, 1961- . Boston, G. K. Hall, 1962- . Quarterly with annual cumulations. $\$ 17.50$ per yr.; outside U. S., $\$ 19.25$.

Latin America in Periodical Literature. v. 1, no. 1- . Jan. 1962- . Los Angeles, Center of Latin American Studies, University of California, Los Angeles, 1962- . Monthly. $\$ 4$ per yr.

Though there will be a certain amount of overlapping in the coverage of these two welcome new services, they should not be con- 
fused: the first is an index to periodicals published in Latin America; the second an index (with abstracts) to articles on Latin America appearing in periodicals the world over.

Prepared by the Columbus Memorial Library of the Pan American Union and the New York Public Library, Indice general ... provides "a guide to articles appearing in selected Latin American periodicals in the humanities and social sciences" (Introd.). More than three hundred periodicals are listed, though less than half are given complete indexing. The index offers both author and subject approach, subject headings appearing in Spanish with an auxiliary list of corresponding English terms. In addition to 1961 issues, indexing includes periodicals published in 1960 .

Latin America in Periodical Literature, of which seven pilot issues were given limited distribution, is now available on a monthly basis. It aims "to present in summary form the material relating to Latin America included in a large number of periodicals of widely varying subject matter, published in this and other countries" (Foreword). The list of periodicals includes over two hundred and fifty titles, with plans for adding more. A classed arrangement is used, with author and country indexes in each issue. Abtracts will be numbered consecutively throughout the volume; it is to be hoped that the indexes will be cumulated.-E.S.

\section{RELIGION}

Glanzman, George S. and Fitzmyer, Joseph A. An Introductory Bibliography for the Study of Scripture. Westminster, Md., Newman Press, 1962. 135p. (Woodstock Papers, no. 5) $\$ 1.50$.

Compiled by two Jesuit scripture scholars for their students, but useful to a wide public, this annotated list of more than three hundred entries is designed to guide the "student who is beginning theology or the study of Scripture in a serious way ... to basic titles ... and ... the more important secon tary works" (Pref.). Some twenty divisions classify the works by form (periodicals, series, lexica, grammars, introductions, dictionaries, bibliography, etc.) or by subject matter (biblical theology, archaeology, geography, Dead Sea Scrolls, etc.). Entries give full bibliographical information; critical annotations and references to reviews will enhance the value of the work for the student. A list of periodical abbreviations used and an author index are included.-R.K.

\section{THEATER}

Mander, Raymond and Mitchenson, Joe. The Theatres of London. Illus. by Timothy Birdsall. London, Hart-Davis, 1961. 292p. 30s.

Interesting and informative as this volume is today, its usefulness will increase as the years pass and take their toll of London's existing theatres. The work contains historical sketches of more than fifty present-day theatres, with notes on their predecessors, descriptions of the present structures (usually including accounts contemporary with their openings), and some record of important productions and long runs at each house.-E.S.

Mongredien, Georges. Dictionnaire biographique des comediens français $d u \mathrm{XVII}{ }^{\circ}$ siecle. Paris, Centre National de la Recherche, 1961. 239p. 25 n.f.

This concise volume is devoted to biographical information, in some cases very brief, on professional comedians of both sexes in the seventeenth-century French theater. Appended are two listings, one of the principal French theatrical troups (grouped as those under royal patronage and those which were independent), and another of important French and foreign cities with a chronological listing of the French companies which visited them. A bibliography of works consulted by the author adds to the value of the work.-E.L.

\section{Moving Pictures}

Sovetskoe khudozhestvennye fil'my; annotirovannyi katalog. V. 1- . Moskva, Gos-oe izd-vo "Iskusstvo," 1961- . (In progress) At head of title: Vsesouiznyi Gosudarstvennyi Fond Kinofil'mov.

Contents: v. 1. Nemye fil'my 1918-1935; v. 2. Zvukovye fil'my 1930-1957.

This is a catalog of twenty-five hundred Soviet moving pictures, including animated cartoons, produced between 1918 and 1957. Description covers genre, running time, producing organization and date, date of first showing, names of scenarists, directors, actors, author and title of book if an adaptation, statement of theme, plot summary, bibliogra- 
phy of reviews and indication if the film is no longer extant. Artistic evaluation is expressly omitted, with the aim of objective description for historians and theoreticians of the film art. Arrangement is chronological in each volume, the first devoted to silent and the second to sound films. A third volume of indexes is planned.-E.B.

\section{DICTIONARY}

The Kosciuszko Foundation Dictionary: English-Polish, Polish-English, by K. Bulas, L. L. Thomas and F. J. Whitfield. The Hague, Mouton, 1959-61. 2v. (Poland's millennium series of the Kosciuszko Foundation) f. 70 the set. (Also distributed by the Kosciuszko Foundation, 15 East 65th St., New York 21; \$10 per volume), v. 1, English-Polish, 1037p.; v. 2, Polish-English, 772p.

Publication of the second volume completes this substantial and scholarly bilingual dictionary. Volume two omits the dialect, slang and peculiarly British or American words included in the first volume, being "restricted to twentieth century standard Polish" (Foreword). It contains an abbreviations list and a list of corrections and additions to both volumes.-E.B.

\section{LITERATURE}

Lexikon der Weltliteratur im 20. Jahrhundert. Freiburg: Herder, [1960-61]. 2v. DM.84,- -

Very comprehensive within its two-volume limit, this work devotes space to every major national literature, although author entries are predominantly Western. Bibliographies at the ends of articles (almost all of which are signed) and an index in volume two to all authors, including those who are mentioned but do not have individual articles, are among the useful features of the Lexikon.

It should be noted that the articles are primarily of a subjective, critical nature so that the usefulness of the work for reference purposes is largely limited to the biographical material and to the bibliographies.-E.L.

Mummendey, Richard. Die schöne Literatur der Vereinigten Staaten von Amerika in deutschen Ubersetzungen; eine Bibliographie. Bonn, H. Bouvier; Charlottesville, Bibliographical Society of the University of Virginia, 1961. 199p. \$12.50.
Added title page in English; prefatory matter in English and German.

Compiled from German and American publishers' lists, biographical reference works, and library catalogs, this bibliography lists separately-published German translations of literary works of American authors. Entry is by author, with collected editions, if any, followed by individual works. After original title and date of publication are given the translated title, translator, full imprint, and pagination of the translation. Since for many works there is more than one translation or edition, the actual total is well beyond the 1887 numbered entries. A similar bibliography for translations appearing in periodicals and collections is contemplated.-E.S.

U. S. Library of Congress. Eighteenth Century Russian Publications in the Library of Congress; a Catalog. Prepared by Tatiana Fessenko. Washington, Slavic and Central European Division, Reference Dept., Library of Congress, 1961. 157p. \$1.

One of the most extensive collections of eighteenth-century Russian books outside the Soviet Union is that of the Library of Congress. Dr. Sergius Yakobson points out in the Preface that the 1316 fully cataloged works in this bibliography compare, for example, with 2745 in the published catalog of the State Public Library of the Ukraine. The person chiefly responsible for their cataloging, Mrs. Fessenko, ". . . in almost one hundred instances has succeeded in identifying the foreign authors of Russian translations which up to now have been listed as anonymous in Russian bibliographies." Other tentative identifications are listed in an appendix.-E.B.

Walker, Warren S., comp. Twentieth-Century Short Story Explication; Interpretations, 1900-1960 Inclusive, of Short Fiction since 1800. Hamden, Conn., Shoe String Press, 1961. 369p. \$6.

A "bibliography of short story explication published from 1900 through 1960 in books, monographs, and periodicals" in English, except for important articles in a small number of "readily available foreign-language journals" (Pref.). Only interpretive material is listed; studies of sources, biographical and background materials being excluded. Arrangement is alphabetical by author treated, then by story title and within this subdivi- 
sion by author of the interpretation. Full bibliographical details are given in each entry, with journal titles abbreviated as in Wilson indexes. There is an index of authors treated, made necessary by lack of running heads. Spot checking shows that this volume is somewhat more extensive in coverage than Jarvis A. Thurston's similar Short Fiction Criticism . . since 1925 (Denver, Swallow, 1960) which had a closing date of 1958 for stories treated, and confined itself to Englishlanguage entries. However, as both compilers have used the same standard sources, many author bibliographies are identical in the two works.-R.K.

\section{SPEECH}

Mulgrave, Dorothy Irene [and others]. Bibliography of Speech and Allied Areas, 19501960. Philadelphia, Chilton, [1962]. 184p. $\$ 6.50$.

“This selective bibliography contains a compilation of doctoral dissertations and books that relate to speech and allied areas completed during the years 1950 to 1960 . By allied areas is meant fields of research in which the subject matter relates directly to the areas of speech and drama" (Introd.). A subject arrangement similar to that used in the listings of doctoral dissertations in Speech Monographs, but with further subdivisions, is employed. Books and theses are separately grouped. In view of the obvious amount of work which went into this compilation, it is regrettable that either the coverage of dissertations was not meant to be comprehensive, or that a definite statement regarding selection criteria was not included. Equally regrettable is the lack of an index.-E.S.

\section{BIOGRAPHY}

Chambers's Biographical Dictionary, ed. by J. O. Thorne. New edition. New York, St Martin's Press, [1962]. 1432p. \$15.

Newly edited and greatly revised, the new Chambers's contains 15,000 entries of universal coverage in contrast to the 11,000 entries of the previous edition. The deletion or abbreviation of outdated articles has created space for both contemporary and historic figures who have recently come into their own, while the addition of a categorized subject index makes the dictionary a useful tool for linking the deed with the man. Bibliographical references are much more plentiful than in the old edition.-E.L.

Delaney, John J. and Tobin, James Edward. Dictionary of Catholic Biography. Garden City, N.Y., Doubleday, [cl961]. 1245p. $\$ 18.50 ; \$ 19.95$ thumb-indexed.

An alphabetical directory, designed for popular use, of almost fifteen thousand Catholics who have made "a significant contribution to the Church" or "to the many areas of human endeaver" (Foreword). Names are not limited by country or era, but living persons are excluded. Entries range in length from one-line identifications to a page. Only accounts of major figures carry bibliographies and these are often limited to a single volume, usually a popular biography. Lists of saints as patrons, saints' symbols in art, and chronological lists of popes and world rulers are appended. The text is set in a twocolumn page of pleasing typeface.-R.K.

Segal, Ronald. Political Africa; a Who's Who of Personalities and Parties. London, Stevens and Sons, 1961. 475p. 50s.

Artique, Pierre. Qui sont les leaders congolais? [Ed. 1961] Bruxelles, Editions EuropeAfrique (49-51 Ave. du Domain), 1961. 375p. (Collections Carrefours Africains, dir. par Jaques Marres).

More than half of Political Africa consists of biographical sketches of several hundred persons prominent in African political life. The accounts are textual in form, varying in length from a brief paragraph to several pages. Emphasis is on public career and political activity, and the whole "is not ... a dictionary of politics drained dry of all opinion" (Pref.). In the second section, under country or other political unit, there are descriptive accounts of the organization and activities of the various political parties and movements in each. No sources or other bibliographical data are cited.

The second edition (1st, 1960) of Qui sont les leaders congolais? attempts to provide much the same kind of information for a smaller area. Coverage is much wider, including not only lesser political figures but many others in related activities. Information for each person is generally brief, with frequently only an identifying line or two. Appended are a listing of political parties and 
other public associations, a chronology of Congolese events, and a list of abbreviations. -J.N.W.

Who's Who in Soviet Social Sciences, Humanities, Art and Government, comp. by Ina Telberg. New York, Telberg Book Co., 1961. 147p. $\$ 9.80$.

Using the third edition of the Malaia sovetskaia entsiklopediia (Supplement 3D14), the compiler has translated brief biographical data for approximately seven hundred living persons in the fields other than science. "It is interesting that the professions most successful in achieving this distinction are writers, with government V.I.P.'s only slightly ahead of poets. With the exception of the academic groups the Who's Who includes a much larger number of women and non-Russians than the Who's Who in Soviet Science and Technology" (Introd.). An index by professions, a Russian name index and an index of pseudonyms add considerably to the usefulness of this volume in comparison with its companion volume for scientists, and the size of the mimeographed page has been reduced to a more normal $81 / 2 \times 11$ inches. -E.B.

\section{GEOGRAPHY}

British Association for the Advancement of Science. Research Committee. A Glossary of Geographical Terms. Ed. by L. Dudley Stamp. New York, Wiley, [1961]. 539p. $\$ 10$.

A pioneer effort in the field, this glossary covers physical, human, social, and economic geography. It excludes "ordinary dictionary words" and is "limited to terms used in current geographical literature written in English. Foreign words are only included if they are in use in their original form, untranslated, in works written in English" (Pref.). When there is no doubt as to the meaning, the definition is quoted without comment from the O.E.D. or other standard source. In the case of variant or changed meanings, additional quotations are used, sometimes followed by a comment from a member of the editorial committee. Appendices include a list of commonly used Greek and Latin roots, and lists of foreign language terms absorbed into English geographical literature.-E.S.

\section{HISTORY}

Crick, Bernard R., ed. A Guide to Manuscripts Relating to America in Great Britain and Ireland. Ed. by B. R. Crick and Miriam Alman under the general supervision of H. L. Beales. [London], Published for the British Association for American Studies by the Oxford University Press, 1961. 667p. $\$ 13.45$.

Within a geographical arrangement this guide provides location and brief descriptions for all manuscripts in some three hundred repositories (73 in London alone) in Great Britain and Ireland relating to the history and literature, in the widest possible sense, of the American colonies and the United States. The volume complements and in general does not incorporate materials listed in the three pre-World War I Carnegie Institution volumes (Guide V94); even so, Crick requires 54 pages to list added materials for the British Museum, 40 for the Public Record Office. A tremendous amount of material is noted, and a model introduction, index, valuable headnotes to various sections, annotations, and hundreds of bibliographical footnote references combine to make this a comprehensive, scholarly handbook. The editors note that occasional lists of addenda may be listed in the Bulletin of the British Association for American Studies.-E.J.R.

Dumond, Dwight Lowell. A Bibliography of Antislavery in America. Ann Arbor, University of Michigan Press, [1961]. 119p. $\$ 10$.

This listing of "printed anti-slavery literature written and circulated by those active in the anti-slavery movement" ranges from the late eighteenth century to the 1860's, and includes materials such as broadsides, serials, speeches, and sermons as well as pamphlets and books. British items widely circulated in the United States are also included. Arrangement is alphabetic, with complete imprint given. The author states, "It is believed that no item of major importance has been overlooked."-E.J.R.

Hale, Richard W., ed. Guide to Photocopied Historical Materials in the United States and Canada. Ithaca, N.Y., Cornell University Press for the American Historical Association, [c1961]. 24lp. \$5.

This union list, prepared by the American 
Historical Association's Committee on Documentary Reproduction, is designed as an aid in locating primary source materials, and supplies "basic bibliographical information on the photocopied manuscripts of interest to historians, which are available in depositories in the United States and Canada" (Pref.). Entries include author or compiler; description; dates; amount and location of originals; type and location of photocopy; "generations" available and information as to whether or not the photocopy has regenerative qualities. Over-all arrangement is that of the Association's Guide to Historical Literature, by geographic or political division. Within a subdivision, materials are grouped as government and church records, business and personal papers, and records of institutions. About three quarters of the eleven thousand entries are devoted to the United States. A bibliography of finding aids to photocopied materials, and an index are included.-R.K.

Lehmann, Ruth Pauline. Nova Bibliotheca Anglo-Judaica; A Bibliographical Guide to Anglo-Jewish History, 1937-1960. London, Jewish Historical Society of England, 1961. 232p. 30s.

Prepared as a supplement to Cecil Roth's Magna Bibliotheca Anglo-Judaica (Guide $\mathrm{K} 239$ ), this volume extends the coverage from 1937 to 1960 . However, the bibliography "is not intended to be exhaustive and no attempt is made to supplement Part II [consisting mainly of source material to 1837] of the Magna Bibliotheca, only those sections having a direct bearing on Anglo-Jewish history being brought up to date" (Introd.). Arrangement generally follows that of the earlier work, with the addition of some new subsections. Fully indexed.-E.S.

New York. Public Library. Reference Dept. Dictionary Catalog of the History of the Americas. Boston, G. K. Hall, 1961. 28v. $\$ 1,280$.

Yale University. Library. A Catalog of the Yale Collection of Western Americana. Boston, G. K. Hall, [1961]. 4v. \$185.

Two additions to the publisher's list of photographic reproductions in book form of library catalogs, these sets evince the advantages and disadvantages more or less common to these publications: the advantage of making generally available the catalog of a dis- tinguished subject collection, and the disadvantage of a thoroughly unattractive and sometimes all but unreadable page.

The New York Public Library volumes contain nearly six hundred thousand author, subject, and other entries representing one of the world's best known collections in North and South American history and allied topics. In addition to the holdings of the library's American history division, there are cards for many relevant items from other parts of the library's collections, e.g., biography, government documents, social science, etc. Particularly useful are the numerous subject cards for periodical articles indexed by the library. There is no preface or other explanatory matter. Cut-off date is presumably 1960.

In the Yale set, volumes 1-3 present the complete uthor-subject catalog of their Western Americana Collection; volume 4 reproduces the shelf-list cards, thereby providing a classed guide to the material. The Preface warns that, "although many common books are included, the Collection is primarily a rare-book rather than a complete working collection," and therefore does not pretend to include the vast bulk of Yale's holdings in the field.-E.S.

Rosenthal, Eric. Encyclopaedia of Southern Africa. London, Frederick Warne and Co., 1961. 600p. 42s.

As the "first" encyclopedia on southern Africa this one-volume work should be a welcome addition to materials on that area. It contains five thousand entries, some of which are signed, "ranging from History, Biography and Literature ... to Geography, Geology, and Natural History" as well as many colloquialisms. Maps and illustrations enliven the format.-E.L.

Santschy, Jean-Louis. Manuel analytique et critique de bibliographie generale de l'historie suisse. Berne, Herbert Lang, 1961. 250p. 28 Sw. fr.

Not a bibliography of Swiss history as such, this work is rather a scholarly and detailed guide to sources and a bibliography of bibliographies for use of the specialist in the field. The chapter arrangement is intricate, with materials grouped according to form and date. Sources treated are general, archival, periodical, and monographic, with full annotations and explanations of the 
nature and potential use of the items listed. Periodical articles and critical reviews are included, and for the more important monographs tables of contents are often given. There are indexes of main entries and of subjects.-J.N.W.

\section{Classical Antiquities}

Akademiia Nauk SSSR. Institut Istorii. Drevniaia Gretsiia i drevnii Rim; bibliograflcheskii ukazatel' izdanii vyshedshikh v SSSR 1895-1959. Sostavitel' A. I. Voronkov. Moskva, 1961. 522p. 4 rubles, 38 kopeks.

This is a classified bibliography of studies published in pre-Revolutionary Russia and in the Soviet Union between 1895 and 1959, in the Russian, Greek, or Latin languages. Some Byzantine and mediaeval materials are listed when they relate to authors of antiquity, transmitting texts. All phases of
Greek and Roman culture are included, as well as the history of the teaching of classical subjects. There is an index for modern authors, translators, editors, and reviewers.E.B.

The New Century Classical Handbook, ed. by Catherine B. Avery. Editorial consultant, Jotham Johnson. New York, Appleton-Century-Crofts, 1962. 1162p. illus. $\$ 15$.

Designed for the general reader and the student, this work presents in one alphabet much clear and concise information on people (real and imaginary), gods, legends, places, literary titles, allusions, etc., connected with the classical world. (There are very few articles under common nouns.) Sketches vary in length from a few lines to several pages, none signed; nor are there any bibliographies or cross references. Pronunciation is indicated. There are many handsome plates, well reproduced, but placed with no relation to the text and not indexed.-J.N.W.

\section{Clerical Aptitude ...}

(Continued from page 314)

has scored high in the test he can be told that if he takes it slowly at first in order to learn the routine, speed will come naturally. If he has scored below average and is hired, he should be told honestly that he need to be careful in his work since he will be prone to error if he attempts to speed up beyond his ability.

In summary, the measurement of the clerical aptitude of an applicant can enable an administrator to avoid the expense, frustration, and loss of efficiency that will result from hiring unqualified personnel. Use of the Minnesota Clerical Test will provide such information as verbal and number aptitude and the relative speed and accuracy of an applicant in each area. The inexpensiveness, the simplicity of administration and scor- ing, and the numerous aids to interpretation make this test an excellent instrument for the detailed measurement of clerical aptitude.

However, as is the case with most tests of this type, its usefulness depends ultimately on the experience and judgment of the person interpreting it. Only in the cases of very high and very low scores can an administrator give this test extra weight in his final decision. As one's experience in using the test grows, its usefulness will increase and refinements in usage will undoubtedly be discovered by the more imaginative. But even at the outset, the negative value of the test is high. Almost without fail, it will provide the information without which a hopelessly clerically inept person might have been hired. 